\title{
Seedling and Slow Rusting Resistance to Leaf Rust in Chinese Wheat Cultivars
}

\author{
Z. F. Li, Department of Plant Pathology, College of Plant Protection, Agricultural University of Hebei, Biological \\ Control Center for Plant Diseases and Plant Pests of Hebei, 289 Lingyusi Street, Baoding 071001, Hebei, China; \\ X. C. Xia, Institute of Crop Science, National Wheat Improvement Center, Chinese Academy of Agricultural Sci- \\ ences, 12 Zhongguancun South Street, Beijing 100081, China; Z. H. He, Institute of Crop Science, National Wheat \\ Improvement Center, Chinese Academy of Agricultural Sciences and CIMMYT China Office, 12 Zhongguancun \\ South Street, Beijing 100081, China; X. Li, L. J. Zhang, H. Y. Wang, Q. F. Meng, and W. X. Yang, Department of \\ Plant Pathology, College of Plant Protection, Agricultural University of Hebei, Biological Control Center for Plant \\ Diseases and Plant Pests of Hebei, 289 Lingyusi Street, Baoding 071001, Hebei, China; G. Q. Li, Plant Protection \\ Institute, Chinese Academy of Agricultural Sciences, 2 Yuanmingyuan West Road, Beijing 100091, China; and \\ D. Q. Liu, Department of Plant Pathology, College of Plant Protection, Agricultural University of Hebei, Biological \\ Control Center for Plant Diseases and Plant Pests of Hebei, 289 Lingyusi Street, Baoding 071001, Hebei, China
}

\begin{abstract}
Li, Z. F., Xia, X. C., He, Z. H., Li, X., Zhang, L. J., Wang, H. Y., Meng, Q. F., Yang, W. X., Li, G. Q., and Liu, D. Q. 2010. Seedling and slow rusting resistance to leaf rust in Chinese wheat cultivars. Plant Dis. 94:45-53.

Identification of resistance genes is important for developing leaf rust resistant wheat (Triticum aestivum) cultivars. A total of 102 Chinese winter wheat cultivars and advanced lines were inoculated with 24 pathotypes of Puccinia triticina for postulation of leaf rust resistance genes effective at the seedling stage. These genotypes were also planted in the field for characterization of slow rusting responses to leaf rust in the 2006-07 and 2007-08 cropping seasons. Fourteen leaf rust resistance genes-Lr1, Lr2a, Lr3bg, Lr3ka, Lr14a, Lr16, Lr17a, Lr18, Lr20, Lr23, Lr24, Lr26, Lr34, and LrZH84 - either singly or in combinations, were postulated in 65 genotypes, whereas known resistance genes were not identified in the other 37 accessions. Resistance gene $\operatorname{Lr} 26$ was present in 44 accessions. Genes LrI $4 a$ and $L r 34$ were each detected in seven entries. Lrl and Lr3ka were each found in six cultivars, and five lines possessed Lr16. Lr17a and Lr18 were each identified in four lines. Three cultivars were postulated to possess $L r 3 b g$. Genes $L r 20, L r 24$, and $L r Z H 84$ were each present in two cultivars. Each of the genes $\operatorname{Lr} 2 a$ and $L r 23$ may exist in one line. Fourteen genotypes showed slow leaf rusting resistance in two cropping seasons.
\end{abstract}

Leaf rust, caused by Puccinia triticina Eriks., is one of the most important and widespread diseases of common wheat (Triticum aestivum L.) worldwide. It is adapted to a wide range of environments, occurs wherever wheat is grown, and can cause significant yield and economic losses (38). In China, destructive epidemics of leaf rust occurred in 1969, 1973, 1975, and 1979 (4). During the past decade, leaf rust has periodically caused destructive yield losses in the major wheat production regions, particularly in North China and the Yellow and Huai valleys (42). Resistant cultivars are the most efficient and environmentally friendly method for reducing damage caused by leaf rust (25).

Genetic interactions between wheat and $P$. triticina involve gene-for-gene relationships (27). Gene postulations assume gene-

Corresponding authors:

D. Q. Liu, E-mail: 1dq@hebau.edu.cn

Z. F. Li, E-mail: 1zf7551@yahoo.com.cn

Accepted for publication 9 August 2009.

doi:10.1094/PDIS-94-1-0045

(C) 2010 The American Phytopathological Society for-gene specificities in hypothesizing probable resistance genes present in host genotypes (23). The presence of a specific resistance gene in a host line can be postulated from response arrays of pathogen cultures with known avirulence and virulence characteristics. Many researchers have used this approach to identify leaf rust resistance genes $(L r)$ in various sets of wheat lines. For example, Statler (37) postulated $L r 1, L r 2 a, L r 2 c, L r 10, L r 17 a$, and Lr18 in a group of 25 hard red spring wheat genotypes. McVey (19) identified genes Lr1, Lr3, Lr10, Lr16, Lr24, and Lr26 in 86 winter wheat cultivars from 26 countries using $15 P$. triticina races. Unidentified resistance genes were also present in some cultivars. McVey and Long (20) postulated 14 resistance genes, $L r l$, Lr2a, Lr3, Lr3ka, Lr9, Lr10, Lr11, Lr14a, Lr16, Lr17a, Lr18, Lr24, Lr26, and Lr30, in 30 cultivars, and 56 hard red winter wheat lines from 9 breeding programs using 17 isolates of $P$. triticina with known avirulence or virulence to $16 \mathrm{Lr}$ genes. Fourteen genes, Lrl, Lr3, Lr3bg, LrlO, Lr13, Lrl4a, Lr16, Lr17a, Lrl9, Lr23, $L r 26, L r 27+L r 31$, and $L r 34$, were identified among 76 Mexican wheat cultivars
$(30,35)$. Resistance genes were also postulated in selected soft red winter wheat $(11,38)$ and hard red spring wheat cultivars (22) from the United States, and 36 wheat cultivars from Ethiopia and Germany (21). Singh et al. (31) screened 61 spring and 102 facultative and winter wheat cultivars from China with $14 P$. triticina races and postulated 9 seedling resistance genes, Lr1, Lr3, Lr3bg, Lr10, Lr13, Lr14a, Lr16, $L r 23$, and $L r 26$, in some of the cultivars. However, limited information is available with respect to possible leaf rust resistance genes in current commercial wheat cultivars and advanced lines in China. Therefore, characterization of leaf rust resistance genes in current widely grown Chinese wheat cultivars would be extremely useful for breeding new resistant cultivars and for gene deployment schemes using Chinese wheat germplasm.

To date, 61 leaf rust resistance genes have been cataloged in wheat (18). Most of them confer hypersensitive reactions and interact with the pathogen in a gene-forgene fashion (7). The effectiveness of such genes is often absent or short-lived due to the appearance of pathotypes with corresponding alleles for virulence (10). The pyramiding of several resistance genes in a single cultivar is considered important since their combined effects confer a wider spectrum of resistance (26) and perhaps extends the period of effectiveness. Currently, only a few designated leaf rust resistance genes, such as $\operatorname{Lr} 9, \operatorname{Lr} 19, \operatorname{Lr} 24$, and $L r 38$, are effective against prevalent Chinese $P$. triticina races (39). Hence, it is very important to search for new resistance genes to cope with the rapidly evolving pathogen population.

Adult-plant resistance (APR) of the slow rusting type is considered more durable than seedling resistance (36) or major gene APR. Slow rusting is characterized by slow disease development in the field despite a high infection type (33), and involves a longer latent period, a low infection frequency, smaller uredial size and reduced duration of sporulation, and less 
spore production (2). Of the 61 leaf rust resistance genes cataloged, $\operatorname{Lr} 34$ and $\mathrm{Lr} 46$ are assumed to be slow rusting genes $(32,34)$. Dyck and Samborski (6) found slow rusting resistance gene Lr34 in the Brazilian wheat cultivar Frontana. Dyck (5) located Lr34 on chromosome 7D. Singh (29) and McIntosh (17) reported that Lr34 is genetically associated with gene $\mathrm{Yr} 18$, conferring slow rusting resistance to stripe rust. Both genes are also linked with gene Ltn for leaf tip necrosis in adult plants, a gene that can often be used as a morphological marker for Lr34 and Yr18 (28). Krattinger et al. (12) showed the Lr34 protein resembled ABC (ATP-binding cassette) transporters of a pleiotropic drug resistance subfamily.
Lr34 confers a moderate level of leaf rust resistance when present alone; however, combinations of Lr34 with two to four additional slow rusting genes resulted in high resistance in most environments (33). In addition, Singh et al. (34) identified the gene $L r 46$ for slow leaf rusting and located it on chromosome 1B of cultivar Pavon 76. This gene has remained effective since 1976. Lillemo et al. (15) reported that Lr46 was closely linked to the slow stripe rusting gene Yr29 and powdery mildew resistance gene $P m 39$. The frequent breakdown of leaf rust resistant cultivars has forced wheat breeders to focus on the development of cultivars with durable resistance based on slow rusting genes. Chen et al. (3) screened
7 wheat cultivars with slow rusting resistance to leaf rust in 37 Chinese wheat cultivars based on latent period, epidemic rate, area under disease progress curve (AUDPC), infection type (IT), final disease rating, and accumulation temperature of latent period by the time of pustule eruption up to $50 \%$. Although slow rusting resistance and major genes have been used for durable control of leaf rust, very little information is available on either type of resistance in most current Chinese wheat cultivars.

One hundred and two widely grown Chinese wheat cultivars and advanced lines from 12 provinces in the major wheat production regions were investigated in this study. The objectives were to postulate

Table 1. Pedigrees, origins, and likely presence or absence of the 1B.1R wheat-rye chromosomal translocation and the $L r 34$ leaf rust resistance gene based on molecular markers of 102 Chinese wheat genotypes

\begin{tabular}{|c|c|c|c|c|c|}
\hline Line no. & Genotype & Origin & Pedigree & $1 B .1 R^{a}$ & $L r 34^{b}$ \\
\hline 1 & Han 4599 & Hebei & Han 4032/85Zhong47 & + & - \\
\hline 2 & Han 5316 & Hebei & Han 7808/CA 8059//85Zhong47 & + & - \\
\hline 3 & Aikang 58 & Henan & Zhoumai 11 // Wenmai 6/Zhengzhou 8960 & + & - \\
\hline 4 & Xinmai 208 & Henan & Yumai 18/Jimai 5418 & + & - \\
\hline 5 & Zhoumai 16 & Henan & Zhou 9/Zhou 8425B & + & - \\
\hline 6 & Zhoumai 18 & Henan & Zhou 9/Neixiang 185 & + & - \\
\hline 7 & (95)18 & Shaanxi & $843380 / 81170-1-2-1$ & + & - \\
\hline 8 & Lantian 14 & Gansu & Qingshan 895/Zhongliang 17 & + & - \\
\hline 9 & Lantian 9 & Gansu & Xifeng $16 / 76-89-13$ & + & - \\
\hline 10 & Chuanyu 19 & Sichuan & Chuanyu 5/Mo 460//Mianyang 26 & + & - \\
\hline 11 & N1621-19-4 & Sichuan & Mianyang 26/Yiyuan 2 & + & - \\
\hline 12 & Jing 035-1 & Yunnan & cc & + & - \\
\hline 13 & Zhoumai 12 & Henan & Zhou 8425A/SWD73295 & + & - \\
\hline 14 & $5 \mathrm{R} 608$ & Beijing & R1//Xuezao/D164 & + & _- \\
\hline 15 & $5 \mathrm{R} 610$ & Beijing & 6521-89630278/ K3-ABE//A121 & + & - \\
\hline 16 & Henong 326 & Hebei & $84(252) / 86(298)$ & + & - \\
\hline 17 & Shi 4185 & Hebei & Tal/Zhi 8094//Yumai 2/3/Jimai 26 & + & - \\
\hline 18 & Lankao 906-4 & Henan & 84-184/ Yumai 2//90 Selection & + & - \\
\hline 19 & Jinan 16 & Shandong & Tal Shannongfu 63/AimengniuV & + & _- \\
\hline 20 & Shaan 715 & Shaanxi & Shaan 354/Yanmai 8911 & + & - \\
\hline 21 & Tian 95HF2 & Gansu & Selected from $\mathrm{Tal}$ wheat $\mathrm{F}_{2}$ recurrent selection population & + & - \\
\hline 22 & Huaimai 18 & Jiangsu & Zhengzhou 891/Yan 1604 & + & - \\
\hline 23 & Bi 2002-2 & Guizhou & $8513-1624 / \mathrm{Ji} 1002$ & + & - \\
\hline 24 & $99-0502$ & Sichuan & 911/MY86-51 & + & - \\
\hline 25 & Mian 2000-36 & Sichuan & Mian92-8/Mian88-304//Guinong 19-4 & + & - \\
\hline 26 & N711 & Sichuan & 92-4/Mianyang 4 & + & - \\
\hline 27 & Yumai 47 & Henan & Yumai 2/Baiquan 3199 & - & - \\
\hline 28 & Yannong 19 & Shandong & Yan 1933/Shaan 82-29 & - & - \\
\hline 29 & Lumai 21 & Shandong & Lumai 13/Yumai 2 & - & - \\
\hline 30 & Emai 14 & Hubei & Fan 6/Yanda 72-629 & - & - \\
\hline 31 & Guizhou 98-18 & Guizhou & Sumai 3/C39//Qing 30 & + & - \\
\hline 32 & Zhengmai 9023 & Henan & (Xiaoyan 6/Xinong 65//8323-3/8443)/Shaan 213 & - & - \\
\hline 33 & $5 \mathrm{R} 615$ & Beijing & D221/891162(Agent) & + & - \\
\hline 34 & $5 \mathrm{R} 616$ & Beijing & BL 7You*2/Agent & - & - \\
\hline 35 & Shaannong 981 & Shaanxi & Derived from Shaanyou 225 (Xiaoyan 6/NS2761) & - & - \\
\hline 36 & Een 1 & Hubei & Lovrin 10/761//Sumai 3 & + & - \\
\hline 37 & Xinmai 19 & Henan & C5/Xinxiang 3577//Xinmai 9 & - & - \\
\hline 38 & Xinong 1043 & Shaanxi & Changwu 131/Y 8402 & - & - \\
\hline 39 & An $96-8$ & Anhui & L9288022-21/Xingnong 5 & - & - \\
\hline 40 & 58749 & Sichuan & SW $3243 / 35050 / / 21530$ & + & - \\
\hline 41 & Xinong 1163-4 & Shaanxi & 84Jia79/Xinong 1376 & + & - \\
\hline 42 & $93 \mathrm{Xia032-1}$ & Sichuan & $93-38-1 / 93-35$ & + & - \\
\hline 43 & Y $1496-15$ & Sichuan & 94-2/Mianyang 4 & + & - \\
\hline 44 & Tian 9470 & Gansu & Tian 817/Lantian 6 & + & - \\
\hline 45 & W7 & Sichuan & Durum/Xianyang large spike//W7268 & - & - \\
\hline 46 & LB 0458 & Sichuan & Mianyang $90-310 / \mathrm{M} 180$ & - & - \\
\hline 47 & SW 8588 & Sichuan & Milan's'/SW 5193 & - & - \\
\hline 48 & Lankaoaizao 8 & Henan & $84(184) / 90$ Selection & + & - \\
\hline \multirow[t]{2}{*}{49} & 01-DH689 & Sichuan & 94-D.H-375/Mianyang 26 & + & - \\
\hline & & & & \multicolumn{2}{|c|}{ (continued on next page) } \\
\hline
\end{tabular}

\footnotetext{
${ }^{\mathrm{a}}+=$ presence of $1 \mathrm{BL} .1 \mathrm{RS},-=$ presence of normal 1BL.1BS, determined by the method of Zhang et al. (40).

$\mathrm{b}+=$ presence of $L r 34,-=$ absence of $L r 34$, according to STS marker csLV34 (12).

c $/=$ Unknown.
} 
genes conferring seedling resistance and to assess the likelihood of slow rusting resistance in adult plants grown in the field.

\section{MATERIALS AND METHODS}

Wheat germplasm and $P$. triticina pathotypes. The 102 winter wheat cultivars and advanced lines were from major breeding programs across the autumnsown wheat regions of China, including the provinces of Beijing, Hebei, Henan, Shandong, Shanxi, Shaanxi, Gansu, Anhui, Hubei, Jiangsu, Guizhou, Sichuan, and Yunnan (Table 1). The lines were tested for seedling reaction to $24 P$. triticina pathotypes in the greenhouse and for slow leaf rusting resistance in the field. CIMMYT line Saar with typical slow leaf rusting resistance $(15,40)$ and highly susceptible line Zhengzhou 5389 were used as slow rusting and susceptible controls, respectively. A set of 35 differential lines, mostly near-isogenic lines in the background of Thatcher with known leaf rust resistance genes, were included in the seedling tests, and the ITs displayed by them were used as a basis for postulating resistance genes in the Chinese lines (Tables 2 and 3). The differential lines were kindly provided by the USDA-ARS Cereal Disease Laboratory, University of Minnesota, St Paul, USA. The 24 pathotypes were designated following the coding system of Long and Kolmer (16), with addition of the fourth letter for the reactions to the fourth set of differentials (http://www.ars.usda.gov/SP2 UserFiles/ad_hoc/36400500Cerealrusts/pt_ nomen.pdf). Four Thatcher isogenic lines with genes $L r 1, L r 2 a, L r 2 c$, and $L r 3$ were the first set of differentials; with genes $L r 9, L r 16, L r 24$, and $L r 26$ were the second set of differentials; with genes $L r 3 k a$, Lr11, Lr17a, and Lr30 were the third set of differentials; and with genes $\operatorname{LrB}, \operatorname{Lr} 10$, $L r 14 a$, and $\operatorname{Lr} 18$ were the fourth set of differentials.

Seedling testing. The seedling tests for the 102 cultivars and lines were conducted in 2007 and repeated in 2008, using 24 pathotypes (Table 3), by the method described by Singh et al. (31) with minor

Table 1. (continued from previous page)

\begin{tabular}{|c|c|c|c|c|c|}
\hline Line no. & Genotype & Origin & Pedigree & $1 B .1 R^{a}$ & $L r 34^{b}$ \\
\hline 50 & Chuannong 17 & Sichuan & 91S-23/A302 & + & - \\
\hline 51 & Mian 2000-13 & Sichuan & Mianyang 01821/90Zhong165//Guinong 19-4 & + & - \\
\hline 52 & Chuannong 19 & Sichuan & Qian 1104A/R935 & - & - \\
\hline 53 & Qinnong 151 & Shaanxi & Zhengzi R84019-0-7-5/Xinong 1376 & + & - \\
\hline 54 & $351-15$ & Sichuan & Mian 99-310/GansuM180 & - & - \\
\hline 55 & Neixiang 991 & Henan & 87C27/Zhengzhou 84115// Yumai 13 & + & - \\
\hline 56 & LB 0288 & Sichuan & Mianyang 90-310/M180 & - & - \\
\hline 57 & Zhou 8425B & Henan & Guangmai 74/Lianfeng 1//Predgornayi 2/3/Annong 7959 & + & - \\
\hline 58 & Zhoumai 11 & Henan & Zhou 8425B/Yumai 17 & + & - \\
\hline 59 & 01-018 & Sichuan & Chuannong 21/89-8//89-107 & + & + \\
\hline 60 & R 97 & Sichuan & Mianyang 92-8/91S-5-7 & + & + \\
\hline 61 & Lantian 12 & Gansu & Qingnong 4/Xiannong 4 & - & + \\
\hline 62 & Libellula & Gansu & Tevere/Giuliani//San Pastore (Italy) & - & + \\
\hline 63 & Strampelli & Gansu & Introduced from Italy & - & + \\
\hline 64 & 99422 & Sichuan & Mian 87-19/R1301 & - & + \\
\hline 65 & Chinese Spring & Sichuan & Landrace & - & + \\
\hline 66 & $3 \mathrm{~S} 587$ & Beijing & Bai//108/Flaminio-IDO2229/3/BT 881 & - & - \\
\hline 67 & $5 \mathrm{R} 631$ & Beijing & 93/Yantsr & - & - \\
\hline 68 & Zhongyou 9507 & Beijing & Reselection of Zhongyou 8 & - & - \\
\hline 69 & Henong 822 & Hebei & $88 \mathrm{~S} 522 / 92$ & - & - \\
\hline 70 & Luohan 2 & Henan & Luoyang 78 (111) ai/Jinmai 33 & - & - \\
\hline 71 & Pingyuan 50 & Henan & Landrace & - & - \\
\hline 72 & Xinmai 16 & Henan & Yumai 13/Neixiang 82C6// Yumai 2 & - & - \\
\hline 73 & Xinmai 9 & Henan & Baiquan 3047-3/Neixiang 82C6 & - & - \\
\hline 74 & Yumai 49 & Henan & Bainong 791//Wenxuan 1/Zhengzhou 761/3/Yumai 2 & - & - \\
\hline 75 & Yannong 9 & Shandong & Derived from Bima 1 & - & - \\
\hline 76 & Zimai 12 & Shandong & 917065/910292 & - & - \\
\hline 77 & N95175 & Shaanxi & 92R/Yuancai 142//Xiaoyan 6 & - & - \\
\hline 78 & Shaan 512 & Shaanxi & Shaanmai 150/Shaan 354 & - & - \\
\hline 79 & Xiaoyan 926 & Shaanxi & Derived from Xiaoyan 6 & - & - \\
\hline 80 & Xinong 8925-13 & Shaanxi & Xiaoyan 168/Zhi 763 & - & - \\
\hline 81 & $96-22-2-3$ & Gansu & Cappelle Desprez/935 & - & - \\
\hline 82 & Lantian 17 & Gansu & 92R137/Lantian 6 & - & - \\
\hline 83 & Zhongliang X9610 & Gansu & 92R178/92R178//Chuanjian 134 & - & - \\
\hline 84 & Yangmai 158 & Jiangsu & Yangmai 4/ST1472/506 & - & - \\
\hline 85 & Fengmai 24 & Yunnan & Yunmai 36/Mo 965 & - & - \\
\hline 86 & $4 \mathrm{~S} 589$ & Beijing & Yanda 1817/we1//Tuyou/3/Jing 411*3 & - & - \\
\hline 87 & $4 \mathrm{~S} 615$ & Beijing & T601/Jing $411 * 3$ & - & - \\
\hline 88 & Nongda 189 & Beijing & Lv7you/Yanshi 9//Changfeng 1/H. w y1775/3/Ji 82-4255 & - & - \\
\hline 89 & Henong 215 & Hebei & Anyang 10/Aifeng 1//Beijing 8/3/Lovrin 10/4/HH/5/Orofen & - & - \\
\hline 90 & Xinmai 11 & Henan & Zhou 8826/Xinxiang 3577 & - & - \\
\hline 91 & Xinmai 13 & Henan & Yuanyuanchangbai//C5/Xinxiang 3577 & - & - \\
\hline 92 & Yanzhan 1 & Henan & 89(35)-14/Yumai 18 & - & - \\
\hline 93 & Yanzhan 4110 & Henan & C39/Xibei 78(6)9-2//FR 81-3/Aizao 781-4/3/Aizao 781-4 & - & - \\
\hline 94 & Yumai 18 & Henan & Zhengzhou 761/Yanshi 4 & - & - \\
\hline 95 & Zhoumai 19 & Henan & Zhoumai 13/Shaanyou 225//PH82-2 & - & - \\
\hline 96 & Mingxian 169 & Shanxi & Landrace & - & - \\
\hline 97 & Shaanmai 139 & Shaanxi & $\begin{array}{l}\text { Xiaoyan 22/6/[Triticum dicoccoides AS846//(Shaanmai } \\
\left.\text { 8003/Shaanmai 8007) } \mathrm{F}_{4} / 3 / \text { Shaan } 229 / 4 / \text { Aizaofeng }\right] \mathrm{F}_{3} / 5 / \mathrm{N} 9134\end{array}$ & - & - \\
\hline 98 & $94 t-133$ & Gansu & Hybrid 46/Xiannong 4//Tao 157 & - & - \\
\hline 99 & Zhongliang 98702 & Gansu & Zhongliang 21/92R137 & - & - \\
\hline 100 & Annong 98005 & Anhui & Aizao 781/Wansu 8802 & - & - \\
\hline 101 & Yangfu 2 & Jiangsu & Yangmai 158/101-90 & - & - \\
\hline 102 & Chuannong 21 & Sichuan & 91S-23/Qianhui 3 & - & - \\
\hline
\end{tabular}


modifications. Forty cultivars or lines, with six to eight seeds each, were sown in a plastic growth chamber $(35 \times 24 \mathrm{~cm})$. Zhengzhou 5389 was included as the susceptible control. Seedling inoculations were performed by brushing urediniospores from sporulating susceptible seedlings onto test seedlings when the first leaves were fully expanded. Inoculated seedlings were subsequently placed in plastic-covered cages and incubated at $18^{\circ} \mathrm{C}$ and $100 \%$ relative humidity (RH) for $24 \mathrm{~h}$. They were then transferred to a growth chamber maintained with $12 \mathrm{~h}$ light $/ 12 \mathrm{~h}$ darkness at 18 to $20^{\circ} \mathrm{C}$ with $70 \%$ RH. ITs were scored 10 to 14 days after inoculation according to the 0 to 4 Stakman scale as modified by Roelfs et al. (26). In addition to the genes detected based on reaction patterns to different phenotypes, $L r 26, L r 34$, and $L r Z H 84$ were also confirmed by molecular markers.

Identification of $\mathrm{Lr} 26$ and Lr34. To determine the presence of the 1BL.1RS translocation carrying $\mathrm{Lr} 26$, two molecular markers, one with a specific sequence from the $\omega$-secalin rye gene generating a 1,076-bp fragment in genotypes with the 1BL.1RS translocation, and the other from the wheat $G l u-B 3$ gene generating a 636-bp fragment amplified in genotypes without the 1BL.1RS translocation, were used to assay the 102 cultivars and lines following the procedure developed by Zhang et al. (41) with minor modifications. The slow rusting resistance gene Lr34 was identified using the STS marker csLV34 as described by Lagudah et al. (13) (Table 1).

Field testing. The 104 cultivars and lines, including Saar and Zhengzhou 5389, were planted in a randomized complete block design with three replicates in Baoding, Hebei Province, in the 2006-07 and 2007-08 cropping seasons. Fifty seeds of each line were sown in a single-row plot with $1.5-\mathrm{m}$ length and $30 \mathrm{~cm}$ between rows. Spreader rows of Zhengzhou 5389 were planted perpendicular and adjacent to the test rows. Leaf rust epidemics were initiated by spraying aqueous suspensions of urediniospores of $P$. triticina pathotype THTT, to which a few drops of Tween 20 $(0.03 \%)$ were added, onto the spreader rows at the tillering stage. Disease severities were assessed three times at weekly intervals with the first scoring 4 weeks after inoculation using the modified Cobb scale (24), and ITs were scored using a 0 to 4 scale (26). The disease severity data were used to calculate AUDPC based on the method described by Broers et al. (1). AUDPC was calculated as:

$$
\mathrm{AUDPC}=\sum_{i=1}^{n}\left[\left(X_{i}+X_{i+1}\right) / 2\right]\left(T_{i+1}-T_{i}\right)
$$

where $T_{i}=$ number of days after inoculation and $X_{i}=$ disease severity. The relative AUDPC (rAUDPC) value for each wheat genotype in each cropping season was calculated as the percentage of the AUDPC value of the susceptible check (Zhengzhou 5389). The maximum disease severity (MDS, \%) was recorded for each genotype in each cropping season as percentage of leaf area infected when the susceptible check displayed its MDS.

Statistical analysis. The SAS software was used for analysis of variance (ANOVA) and for determining least standard deviations (LSDs) for comparing the rAUDPC and MDS values among the wheat genotypes. Cultivars and lines that were seedling-susceptible to THTT and had lower or nonsignificantly higher values of MDS and AUDPC than those of

Table 2. Seedling infection types ${ }^{\mathrm{a}}$ on 35 wheat lines with known leaf rust resistance genes when tested with 24 pathotypes of Puccinia triticina collected from China

\begin{tabular}{|c|c|c|c|c|c|c|c|c|c|c|c|c|c|c|c|c|c|c|c|c|c|c|c|c|c|}
\hline \multirow[b]{2}{*}{ Tester } & \multirow[b]{2}{*}{$\begin{array}{c}L r \\
\text { gene }\end{array}$} & \multicolumn{24}{|c|}{ Infection types to Puccinia triticina pathotypes } \\
\hline & & $\begin{array}{l}\overline{\text { PH }} \\
\text { QT }\end{array}$ & $\begin{array}{l}\text { FC } \\
\text { QR }\end{array}$ & $\begin{array}{l}\text { FC } \\
\text { ST }\end{array}$ & $\begin{array}{l}\text { PC } \\
\text { BT }\end{array}$ & $\begin{array}{l}\text { TC } \\
\text { GT }\end{array}$ & $\begin{array}{l}\text { PG } \\
\text { SN }\end{array}$ & $\begin{array}{l}\text { FG } \\
\text { SQ }\end{array}$ & $\begin{array}{l}\text { FK } \\
\text { QT }\end{array}$ & $\begin{array}{l}\text { PC } \\
\text { HS }\end{array}$ & $\begin{array}{l}\text { FB } \\
\text { HT }\end{array}$ & $\begin{array}{l}\text { FH } \\
\text { ST }\end{array}$ & $\begin{array}{l}\text { PH } \\
\text { SS }\end{array}$ & $\begin{array}{l}\text { FH } \\
\text { GS }\end{array}$ & $\begin{array}{l}\text { FH } \\
\text { TS }\end{array}$ & $\begin{array}{l}\text { PG } \\
\text { TT }\end{array}$ & $\begin{array}{l}\text { PC } \\
\text { JT }\end{array}$ & $\begin{array}{l}\text { TC } \\
\text { HT }\end{array}$ & $\begin{array}{l}\text { PH } \\
\text { ST }\end{array}$ & $\begin{array}{l}\text { FH } \\
\text { HQ }\end{array}$ & $\begin{array}{l}\text { FH } \\
\text { TR }\end{array}$ & $\begin{array}{l}\text { PH } \\
\text { JT }\end{array}$ & $\begin{array}{l}\text { TH } \\
\text { TT }\end{array}$ & $\begin{array}{l}\text { FC } \\
\text { TT }\end{array}$ & $\begin{array}{l}\text { PC } \\
\text { GR }\end{array}$ \\
\hline RL 6003 & Lrl & 3 & ;0 & 0 & 3 & 3 & 4 & , & 2 & 3 & ;2 & ;2 & 3 & 0 & 0 & 3 & 3 & 3 & 3 & 0 & 0 & 3 & 4 & ; & 3 \\
\hline RL 6016 & $L r 2 a$ & 1 & 1 & ; & $; 1$ & 3 & $1+$ & $1+$ & ;2 & $; 1$ & ;2 & $; 1$ & 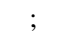 & 0 & 1 & 1 & ;2 & 3 & ; & 0 & $0 ; 2$ & 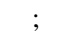 & 4 & ; & ; \\
\hline RL 6019 & $L r 2 b$ & 3 & 4 & 3 & 4 & 3 & 4 & 3 & 3 & 3 & 3 & 3 & 3 & 3 & 3 & 3 & 3 & 3 & 3 & 3 & 3 & 3 & 4 & 4 & 3 \\
\hline RL 6047 & $L r 2 c$ & 3 & 3 & 3 & 4 & 3 & $3 \mathrm{C}$ & 4 & 3 & 3 & 3 & 3 & 3 & 3 & 4 & 3 & 3 & 3 & 3 & 3 & 3 & 3 & 4 & 4 & 3 \\
\hline RL 6002 & Lr3 & 3 & 4 & 3 & 3 & 3 & 4 & 4 & 3 & 3 & 3 & 4 & 3 & 3 & 3 & 3 & 3 & 3 & 3 & 3 & 3 & 4 & 4 & 4- & 3 \\
\hline RL 6042 & Lr3bg & 3 & 3 & 3 & 3 & 3 & 4 & 4 & 3 & 3 & 3 & 3 & 3 & 3 & 3 & 3 & 3 & 2 & 2 & 3 & 2 & 3 & 3 & 4 & 3 \\
\hline RL 6007 & Lr3ka & 3 & 3 & 3 & $; 1$ & ; & 4 & 4 & 3 & 2 & $; 2$ & 3 & 3 & 2 & 3 & 3 & 0 & 0 & 3 & 0 & 3 & $;, 2$ & 3 & 3 & ;2 \\
\hline RL 6010 & $\operatorname{Lr} 9$ & 0 & ; & 0 & 0 & 0 & 0 & 0 & 0 & 0 & . & 0 & 0 & 0 & 0 & 0 & 0 & 0 & 0 & 0 & 0 & 0 & 0 & ; & 0 \\
\hline RL 6004 & Lr10 & 3 & 3 & 3 & 3 & 3 & $2+, 3-$ & 4 & 3 & 3 & 3 & 3 & 3 & 3 & 3 & 3 & 3 & 3 & 3 & 3 & 3 & 3 & 3 & 4 & 3 \\
\hline RL 6053 & $\operatorname{Lr} 11$ & 3 & 3 & 3 & ;12 & 3 & 3 & $3+$ & 3 & 2 & 2 & 3 & 3 & 3 & 3 & 3 & 3 & 3 & 3 & 3 & a & 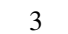 & 3 & 4 & 3 \\
\hline RL 6013 & Lr14a & 3 & 3 & 3 & 4 & 3 & $3 \mathrm{C}$ & 2 & 3 & 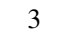 & 3 & 3 & 3 & 3 & 3 & 3 & 3 & 3 & 3 & 2 & 2 & 3 & 3 & 4 & 2 \\
\hline RL 6052 & $\operatorname{Lr} 15$ & 0 & 0 & ; & $; 1$ & ;2 & 4 & $1+$ & ;2 & 3 & $; 1$ & 1 & 3 & ; & 1 & 3 & ; & 1,2 & 1 & 2 & ;2 & ;1 & 3 & $; 1$ & 3 \\
\hline RL 6005 & Lr16 & 3 & 1 & 1 & $1+$ & 2 & 3 & 4 & 3 & 2 & 2 & 3 & 3 & 3 & 3 & 3 & 2 & 2 & 3 & 3 & 4 & 3 & 4 & ;2 & 2 \\
\hline RL 6008 & $L r 17 a$ & 22 & 2 & 3 & ; & 2 & 3 & $3+$ & 2 & 1 & 1 & 3 & 3 & 2 & 3 & 3 & 3 & $; 1$ & 3 & 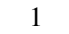 & 2 & 2 & 3 & 3 & 2 \\
\hline RL 6009 & $\operatorname{Lr} 18$ & 3 & 3 & 3 & 3 & 3 & 2 & 1 & 3 & 2 & 3 & 3 & 2 & 2 & 2 & 2 & 3 & 3 & 3 & 2 & 2 & 3 & 3 & 4 & 3 \\
\hline RL 6040 & $\operatorname{Lr} 19$ & 0 & ; & ; & 0 & ; & 0 & ; & 0 & 0 & 0 & 0 & 0 & 0 & ; & 1 & 0 & 2 & 0 & 0 & 0 & 0 & ; & 0 & ; \\
\hline RL 6092 & $\operatorname{Lr} 20$ & 3 & 3 & $; 1$ & $0 ; 1$ & 3 & 4 & ; & ; & 3 & 0 & 3 & 0 & 0 & 0 & 0 & 3 & 3 & ;2 & 3 & 3 & 3 & 3 & 3 & 3 \\
\hline RL 6043 & Lr21 & 0 & $; 1$ & 3 & $; 2$ & ;2 & 3 & 3 & 2 & 2 & 3 & 3 & 12 & 2 & 3 & 2 & 2 & 3 & 3 & 2 & 3 & 3 & 3 & 3 & 2 \\
\hline RL 6012 & $\operatorname{Lr} 23$ & ; & ; & 3 & $; 1$ & $; 2$ & $2+$ & 4 & $; 1$ & 1 & ; & 3 & ; & 12 & $; 1$ & 4 & 4 & 4 & 3 & ;2 & 0 & 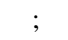 & 3 & $3-$ & $; 1$ \\
\hline RL 6064 & Lr24 & 0 & 0 & ; & ; & 0 & ; & . & 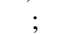 & . & & , & 0 & 0 & 0 & , & ; & 0 & 0 ; & ; & , & & ; & ; & ; \\
\hline RL 6084 & $\operatorname{Lr} 25$ & 3 & 4 & 3 & 4 & 3 & 4 & 4 & 3 & 3 & 3 & 3 & 3 & 3 & 3 & 3 & 3 & 3 & 3 & 3 & 3 & 3 & 3 & 4 & 3 \\
\hline RL 6078 & $L r 26$ & 3 & 3 & 3 & 3 & 4 & $1+$ & 0 & 3 & 3 & ; & 3 & 3 & 3 & 3 & $2+$ & 3 & 3 & 3 & 3 & 3 & $3-$ & 3 & 4 & 3 \\
\hline RL 6079 & $\operatorname{Lr} 28$ & 0 & 0 & ; & 0 & 0 & 0 & ; & 3 & ; & 2 & 0 & 0 & 3 & 0 & 0 & ; & 0 & ; & ; & 3 & 0 & 0 & ; & 0 \\
\hline RL 6080 & Lr29 & 3 & 3 & 3 & $; 2$ & 3 & ; & 4 & ; & ; & ; & 3 & 3 & 3 & 3 & 0 & 1 & ;2 & 3 & 3 & 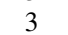 & ;2 & 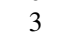 & 3 & 3 \\
\hline RL 6049 & Lr30 & 0 & ; & ; & $; 1$ & $; 1$ & 1 & 1 & 2 & 3 & 3 & & 2 & 2 & 3 & 3 & $0 ; 2$ & 3 & 2 & 3 & 3 & ;2 & 3 & 3 & 2 \\
\hline RL 5497 & Lr32 & ; & ; & ; & $; 1$ & $; 1$ & $2+, 3-$ & 4 & 12 & ;1 & ; & $0 ; 12$ & 1 & $; 1$ & $1+$ & 1 & $; 1$ & ;2 & ; & 3 & 0 & $; 2$ & 3 & 4 & 2 \\
\hline RL 6057 & Lr33 & 3 & 3 & 3 & 3 & 3 & 4 & 4 & 3 & 4 & 3 & 4 & 3 & 4 & 3 & 3 & 4 & 4 & 4 & 3 & 3 & 3 & 3 & $3-$ & 3 \\
\hline E84018 & Lr36 & 3 & $; 1$ & $; 1$ & ; & ; & 2 & $2+$ & 0 & 2 & $; 1$ & ; & ; & 1 & 0 & ; & 2 & 1 & $; 1$ & 2 & 0 & ; & 3 & ; & ; \\
\hline RL 6097 & Lr38 & 0 & 0 & 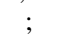 & 0 & 0 & ;1 & $; 1$ & ; & 0 & 0 & ; & ; & 0 & 0 & 0 & 0 & 0 & 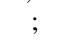 & 0 & 0 & 0 & ; & ; & ; \\
\hline $\begin{array}{l}\text { KS86 } \\
\text { NGRC02 }\end{array}$ & Lr39 & 3 & 3 & ; & ;2 & 2 & 1 & 1 & 2 & 2 & 2 & $; 1$ & $; 1$ & 1 & 2 & 2 & ;2 & $; 2$ & 3 & 3 & 3 & $; 2$ & ; & 1 & 2 \\
\hline $\begin{array}{l}\text { KS91 } \\
\text { WGRC11 }\end{array}$ & $L r 42$ & 0 & 0 & ; & $0 ; 12$ & $; 1$ & $; 1$ & ; & 12 & 2 & $; 2$ & 2 & 2 & 2 & 2 & 2 & 3 & ;2 & 2 & ; & 3 & 0 & $0 ; 1$ & $0 ; 2$ & ; \\
\hline RL 6147 & Lr44 & $3 \mathrm{C}$ & 2 & 3 & 3 & 3 & $1+$ & 3 & 12 & 2 & 2 & 2 & 2 & 2 & 2 & 2 & $1+$ & 1 & 2 & 3 & 1 & 3 & 3 & 3 & 2 \\
\hline & Lr45 & 3 & 3 & ; & 2 & 1 & ; & 1 & 3 & ; & 3 & 3 & 3 & 3 & 3 & 1 & 0 & 2 & 2 & 3 & 3 & 0 & ; & 0 & 3 \\
\hline TcLr50 & Lr50 & 0 & 0 & ; & ; & ; & 4 & 4 & ; & ;2 & ; & $; 1$ & ; & 0 & ; & 3 & ; & 0 & ; & 0 & 0 & ;1 & 3 & ; & 2 \\
\hline RL 6051 & $L r B$ & 4 & 3 & 3 & 3 & 3 & 4 & 4 & 3 & 3 & 4 & 3 & 3 & 3 & 3 & 3 & 3 & 3 & 3 & 3 & 3 & 3 & 3 & 4 & 3 \\
\hline
\end{tabular}

a According to the $0-4$ Stakman scale as modified by Roelfs et al. (26). 
the slow rusting check in field trials were considered to be slow rusting genotypes.

\section{RESULTS}

Resistance genes identified from seedling reactions or molecular markers. Variation in ITs conferred by known $L r$ genes in differential lines, inoculated with 24 P. triticina pathotypes (Table 2), provided an ability to postulate 24 resistance genes (Lr1, Lr2a, Lr3, Lr3bg, Lr3ka, Lr11, Lr14a, Lr15, Lr16, Lr17a, Lr18, Lr20, Lr21, Lr23, Lr26, Lr28, Lr29, Lr30, Lr32, $L r 36, L r 39, L r 42, L r 44$, and Lr50). Resistance genes $\operatorname{Lr} 9, \operatorname{Lr} 19, \operatorname{Lr} 24$, and $\operatorname{Lr} 38$ conferred low ITs with all pathotypes. Postulation of genes $L r 2 b, L r 2 c, L r 3$, $L r 10, L r 25, L r 33$, and $L r B$ was not possible because high ITs were recorded with all pathotypes.

Fourteen resistance genes ( $L r 1, L r 2 a$, Lr3bg, Lr3ka, Lr14a, Lr16, Lr17a, Lr18, Lr20, Lr23, Lr24, Lr26, Lr34, and LrZH84), either singly or in combinations, were postulated to be present in 65 genotypes, whereas 37 accessions carried undetectable or unknown resistance genes (Table 3).

Forty-four entries contained $\operatorname{Lr} 26 ; 12$ displayed low ITs with four $L r 26$-avirulent pathotypes (P6, P7, P10, and P15) and high reactions with the remaining 20 pathotypes, showing the same response pattern as that of RL 6078 carrying Lr26. Thirty-one lines were postulated to possess Lr26 plus other known or unknown $\mathrm{Lr}$ genes according to their low reactions with certain $L r 26$-virulent pathotypes (Tables 2 and 3). All entries postulated to have Lr26 were also confirmed using markers for the presence or absence of the 1BL.1RS translocation (Tables 1 and 3). Three lines (L13 $=$ Zhoumai 12, L26 = N711, and L60 = R97) displayed high ITs to all or some of the four $L r 26$-avirulent pathotypes, but were positive for the presence of 1BL.1RS translocation using the markers. The high ITs with $L r 26$-avirulent pathotypes might be due to an inhibitor of $L r 26$ or to the presence of a $1 \mathrm{RS}$ translocated chromosome not possessing a leaf rust resistance gene. Seven lines might carry Lrl, showing low ITs to 10 pathotypes avirulent to Lrl. Two cultivars (L27 = Yumai 47, and L28 = Yannong 19) are likely to carry gene Lrl alone because they displayed only low ITs with 10 pathotypes avirulent to $L r 1$. Guizhou 98-18 (L31) carried Lr1, Lr26, and the other unidentified genes based on its reaction patterns. Another three cultivars (L29 = Lumai 21, L30 = Emai 14, and L55 = Neixiang 991) were postulated to have $L r l$ and other resistance genes.

Seven lines were postulated to contain Lr14a; they gave low or intermediate reactions to five $L r 14 a$ avirulent pathotypes (P6, P7, P19, P20, and P24). Lr14a was present in combination with $\operatorname{Lr} 26$ in four lines $(\mathrm{L} 41=$ Xinong 1163-4, L42 = 93Xia032-1, L43 = Y 1496-15, and L44 =
Tian 9470). The other three lines (L45 = W7, L46 = LB 0458, and L47 = SW 8588) might carry Lrl4a and other unknown or known genes.

Lr34 was postulated in seven lines with the molecular marker csLv34 (13), and these lines also showed symptoms of leaf tip necrosis $(L t n)$ at the adult stage. Two lines $(\mathrm{L} 59=01-018$, and L60 = R97) carried $L r 34$ in addition to $L r 26$.

Lr3ka was postulated in combination with other known $\mathrm{Lr}$ genes in six lines according to their low reactions to nine Lr3ka-avirulent pathotypes and some Lr3ka-virulent pathotypes.

Gene Lr16 may be present in five lines, showing low ITs with the 10 pathotypes that were avirulent on the Lr16 NIL (Tables 2 and 3). Lrl6 was present in combination with Lr3ka in Shaannong 981 (L35) because low ITs were observed in seedlings inoculated with $10 \mathrm{Lr} / 6$-avirulent pathotypes and three Lr3ka-avirulent pathotypes (P13, P19, and P21). Een 1 (L36) carried Lrl6 in addition to Lr3ka and $L r 26$ according to its low reactions to all pathotypes avirulent to the three genes. Another three lines $(\mathrm{L} 32=$ Zhengmai 9023, L40 = 58749, and L56 = LB 0288) may carry Lrl6 and other known or unidentified genes.

$L r 17 a$ and $\operatorname{Lr} 18$ were each found in four lines. The four lines carrying $L r 17 a$ displayed low ITs to $11 \quad L r 17 a$-avirulent pathotypes. $L r 17 a$ and $L r 3 k a$ were present in An 96-8 (L39), and LrI7a was postulated in combination with $L r 3 k a, L r l 6$, and Lr26 in line 58749 (L40). Xinmai 19 (L37) and Xinong 1043 (L38) may contain Lr17a and other unknown genes. Lr18 was postulated in combination with $\operatorname{Lr} 26$ in four lines $($ L48 = Lankaoaizao 8, L49 = 01DH689, L50 = Chuannong 17, and L51 = Mian 2000-13) based on low ITs with four Lr26-avirulent pathotypes (P6, P7, P10, and P15) and intermediate ITs with five Lr18-avirulent pathotypes (P9, P12-P14, and P19).

Three lines displayed intermediate or low ITs to three pathotypes (P17, P18, and P20) lacking virulence for $\mathrm{Lr} 3 b g$, indicating that they contain Lr3bg. Lr3bg was postulated in combination with $L r 26$ in Qinnong 151 (L53) and in combination with $L r 2 a$ in 351-15 (L54). Chuannong 19 (L52) was postulated to have Lr3bg and other unidentified genes.

Lr20 was detected in Neixiang 991 (L55) in combination with $L r 1$, and LB 0288 (L56) carried known $L r$ genes additional to Lr20. 5R615 (L33) and 5R616 (L34) showed high levels of resistance to all 24 pathotypes and may contain $L r 24$ because the two lines were derived from Agent, a known Lr24 carrier (Table 1). 5R615 also possessed Lr26, as it had the 1BL.1RS translocation detected with molecular markers. LrZH84 was present in combination with Lr26 in Zhou 8425B (L57). According to Zhao et al. (42), Zhou
8425B contains gene $\operatorname{LrZH84}$. Zhoumai 11 (L58) is a derivative of Zhou $8425 \mathrm{~B}$ and had a reaction pattern similar to that of Zhou $8425 B$, indicating that it may also carry $\mathrm{LrZH} 84$.

Line 351-15 (L54) displayed low ITs with all 21 pathotypes avirulent to $L r 2 a$ and an intermediate IT to P17 (TCHT) which is avirulent for $\mathrm{Lr} 3 \mathrm{bg}$, indicating that $L r 2 a$ is present in combination with Lr3bg in this line. Lr23 was present in combination with LrI6 and $\mathrm{Lr} 20$ in LB 0288 (L91), displaying low ITs with pathotypes lacking virulence for $\operatorname{Lr} 16, \operatorname{Lr} 20$, and Lr23.

Eighteen genotypes (L85-L102) showed high ITs with all pathotypes, indicating that they do not have any resistance gene corresponding to an avirulence gene present in any of the pathotypes. The reactions of 18 cultivars and lines (L66 and L68-L84) were not consistent with the response of any known resistance gene or predicted response of any gene combination.

5R631 (L67) conferred resistance to all pathotypes tested, indicating that it carries one or more unidentified resistance genes.

Slow rusting resistance in field tests. Highly significant differences were found for wheat genotypes and environments (years) for rAUDPC and MDS in the field trials (Table 4). The genotype-environment interaction was also significant, but its effect on variation was much less than the genotypic differences.

The MDS value of the susceptible check, Zhengzhou 5389, was 100 and $85 \%$, respectively, in the 2006-07 and 2007-08 cropping seasons (Table 5), indicating that the disease developed well in both seasons. The MDS value of the slow rusting check, Saar, was 18 and $12 \%$, respectively, and its rAUDPC was $15 \%$ in both seasons (Table 5).

Twelve entries, including 5R608 (L14), 5R610 (L15), Tian 95HF2 (L21), Bi 20022 (L23), Guizhou 98-18 (L31), 5R615 (L33), 5R616 (L34), Xinong 1163-4 (L41), LB0288 (L56) Zhou 8425B (L57), Zhoumai 11 (L58), and 5R631 (L67), were highly resistant to pathotype THTT at both the seedling and adult stages. Fifteen genotypes exhibiting high ITs at the seedling stage showed slow leaf rusting resistance in the field to the same pathotype in both seasons (Table 5). The correlations of MDS and relative AUDPC between the two cropping seasons were 0.77 and 0.74 (N = 104 and $P=0.01$ ), respectively, indicating highly consistent results for slow rusting resistance. The correlation between relative AUDPC and MDS at the two locations varied from 0.96 to 0.99 ( $\mathrm{N}=104$ and $P=0.01)$, indicating that MDS was a reliable indicator of AUDPC (14).

\section{DISCUSSION}

Seedling tests for leaf rust response. Yuan et al. (39) postulated 10 known 
Table 3. Seedling infection types ${ }^{\mathrm{a}}$ of 102 wheat cultivars and lines when tested with 24 pathotypes of Puccinia triticina collected from China

\begin{tabular}{|c|c|c|c|c|c|c|c|c|c|c|c|c|c|c|c|c|c|c|c|c|c|c|c|c|c|}
\hline \multirow[b]{2}{*}{$\begin{array}{l}\text { Line } \\
\text { no. }\end{array}$} & \multirow[b]{2}{*}{$\begin{array}{c}L r \\
\text { gene }\end{array}$} & \multicolumn{24}{|c|}{ Infection types to Puccinia triticina pathotypes } \\
\hline & & $\begin{array}{l}\text { PH } \\
\text { QT }\end{array}$ & $\begin{array}{l}\text { FC } \\
\text { QR }\end{array}$ & $\begin{array}{l}\text { FC } \\
\text { ST }\end{array}$ & $\begin{array}{l}\text { PC } \\
\text { BT }\end{array}$ & $\begin{array}{l}\text { TC } \\
\text { GT }\end{array}$ & $\begin{array}{l}\text { PG } \\
\text { SN }\end{array}$ & $\begin{array}{l}\text { FG } \\
\text { SQ }\end{array}$ & $\begin{array}{l}\text { FK } \\
\text { QT }\end{array}$ & $\begin{array}{l}\text { PC } \\
\text { HS }\end{array}$ & $\begin{array}{l}\text { FB } \\
\text { HT }\end{array}$ & $\begin{array}{l}\text { FH } \\
\text { ST }\end{array}$ & $\begin{array}{l}\text { PH } \\
\text { SS }\end{array}$ & $\begin{array}{l}\text { FH } \\
\text { GS }\end{array}$ & $\begin{array}{c}\text { FH } \\
\text { TS }\end{array}$ & $\begin{array}{l}\text { PG } \\
\text { TT }\end{array}$ & $\begin{array}{l}\text { PC } \\
\text { JT }\end{array}$ & $\begin{array}{l}\text { TC } \\
\text { HT }\end{array}$ & $\begin{array}{l}\text { PH } \\
\text { ST }\end{array}$ & $\begin{array}{l}\text { FH } \\
\text { HQ }\end{array}$ & $\begin{array}{l}\text { FH } \\
\text { TR }\end{array}$ & $\begin{array}{c}\text { PH } \\
\text { JT }\end{array}$ & $\begin{array}{l}\text { TH } \\
\text { TT }\end{array}$ & $\begin{array}{l}\text { FC } \\
\text { TT }\end{array}$ & $\begin{array}{l}\text { PC } \\
\text { GR }\end{array}$ \\
\hline 1 & Lr26 & $3 \mathrm{C}$ & 4 & 4 & 4 & 4 & $1+$ & $; 1$ & 4 & 4 & $; 1$ & 3 & 3 & 4 & 4 & $1+$ & 4 & 4 & 4 & 4 & 4 & 4 & 4 & 4 & 4 \\
\hline 2 & Lr26 & $3 \mathrm{C}$ & 4 & 4 & $3 \mathrm{C}$ & 4 & $1+$ & $; 1$ & 4 & 4 & ;1 & 3 & 3 & 4 & 4 & $1+$ & 4 & 4 & 4 & 4 & 4 & 4 & 4 & 4 & 4 \\
\hline 3 & $\operatorname{Lr} 26$ & $3 \mathrm{C}$ & $3+$ & 4 & $3+$ & 4 & 2 & ; & 4 & 3 & 1 & 4 & 3 & 4 & 4 & 1 & 4 & 3 & 4 & 4 & 4 & 4 & 4 & 4 & 4 \\
\hline 4 & Lr26 & 3 & 4 & 3 & 3 & 4 & 2 & $; 1$ & 4 & $3+$ & 0 & 4 & 4 & 4 & 3 & $1+, 2$ & 4 & 4 & 4 & 3 & 3 & 4 & 4 & 4 & 4 \\
\hline 5 & $L r 26$ & 3 & 4 & 4 & 3 & 4 & $1+$ & $; 1$ & 4 & 3 & ; & 3 & 4 & 4 & 4 & 12 & 4 & 4 & 4 & 4 & 4 & 4 & 4 & 4 & 4 \\
\hline 6 & $L r 26$ & $3 \mathrm{C}$ & 4 & 4 & $3 \mathrm{C}$ & 4 & $1+$ & $; 1$ & 4 & 3 & 0 & 4 & 3 & 4 & 3 & $1+$ & 4 & 4 & 4 & $3+$ & 3 & 4 & 4 & 4 & 4 \\
\hline 7 & Lr26 & 3 & $3+$ & $3+$ & 3 & $3+$ & $1+$ & ; & 4 & 3 & ; & 3 & 3 & 4 & 3 & 2 & 4 & 4 & 3 & 4 & 4 & 4 & 4 & 4 & 4 \\
\hline 8 & Lr26 & 3 & $3+$ & 4 & 4 & 4 & $1+$ & ; & 4 & 3 & $; 1$ & 3 & 3 & 4 & 4 & 12 & 4 & 4 & 4 & 4 & 4 & 4 & 4 & 4 & 4 \\
\hline 9 & $\operatorname{Lr} 26$ & 3 & 4 & 4 & 4 & 4 & $; 1$ & 0 & 3 & 3 & 0 & 4 & 3 & 4 & 4 & 2 & 4 & 4 & 4 & 4 & 4 & 4 & 4 & 4 & 4 \\
\hline 10 & Lr26 & 3 & 3 & 4 & 3 & 4 & 1 & ; & 3 & 3 & ; & 3 & $3+$ & 3 & 3 & 1 & 4 & 4 & 3 & $3+$ & 4 & 4 & $3-$ & 4 & 4 \\
\hline 11 & Lr26 & 3 & 4 & 4 & 3 & 4 & $1+$ & ; & 4 & 3 & 2 & 3 & 4 & 4 & 4 & 2 & 4 & 4 & 4 & 4 & 4 & 4 & 4 & 4 & 4 \\
\hline 12 & $\operatorname{Lr} 26$ & 3 & 4 & 4 & $3+$ & 4 & $1+$ & ; & 4 & 3 & 0 & 3 & 3 & 4 & 3 & 2 & 3 & 4 & 4 & 4 & 4 & 4 & 4 & 4 & 4 \\
\hline 13 & $\operatorname{Lr} 26^{\mathrm{c}}$ & 4 & 4 & 4 & 4 & 4 & 4 & 4 & 4 & 4 & 4 & 4 & 4 & 4 & 4 & 4 & 4 & 4 & 4 & 4 & 4 & 4 & 4 & 4 & 4 \\
\hline 14 & $L r 26^{\mathrm{d}_{+}}$ & 0 & 0 & 0 & 0 & 0 & ; & 0 & 0 & 0 & ; & 0 & 0 & 0 & 0 & 0 & 0 & 0 & 0 & 0 & 0 & 0 & 0 & ; & 0 \\
\hline 15 & $\operatorname{Lr} 26^{\mathrm{d}}+$ & ; & ; & ; & ; & ; & 0 & 0 & 1 & 0 & 0 & 0 & 0 & ; & 0 & 0 & ; & ; & ; & ; & ; & 0 & 0 & ; & ; \\
\hline 16 & Lr26+ & $2+$ & $3+$ & $2+, 3 \mathrm{C}$ & $22+$ & 2 & $1+$ & ; & 4 & $2+, 3-$ & 1 & 3 & 3 & 3 & 4 & $; 1+$ & 4 & 4 & 3 & 4 & 4 & 3 & 3 & 4 & 4 \\
\hline 17 & Lr26+ & 2 & 0 & 0 & 0 & 0 & ; & 0 & 0 & 3 & 0 & 3 & 3 & 0 & 3 & 0 & 3 & 3 & ; & 2 & 0 & 3 & ; & 3 & 3 \\
\hline 18 & $\operatorname{Lr} 26+$ & 3 & $3 \mathrm{C}$ & 2 & 2 & 2 & $; 1$ & 0 & 4 & 2 & 0 & 3 & 3 & 3 & 4 & ;1 & 3 & 4 & 2 & 4 & 4 & $2+, 3-$ & 3 & 3 & 4 \\
\hline 19 & $\operatorname{Lr} 26+$ & 3 & 3 & 3 & 3 & 4 & 1 & $; 1$ & $; 2$ & 2 & 0 & 2 & 3 & ;0 & 2 & 2 & 2 & 3 & 3 & 3 & 4 & 4 & 3 & 3 & 0 \\
\hline 20 & Lr26+ & 2 & 3 & 3 & 3 & 3 & $1+$ & 1 & 3 & 3 & 0 & 3 & 3 & 2 & 3 & 2 & 3 & 3 & 3 & 3 & 3 & 3 & 3 & 3 & 3 \\
\hline 21 & $\operatorname{Lr} 26^{\mathrm{d}}+$ & 2 & 0 & ; & 0 & $; 1$ & ; & ; & ; & 0 & ; & ; & 0 & 0 & 0 & 0 & 0 & ;2 & ; & 0 & 0 & 0 & ; & ; & 0 \\
\hline 22 & Lr26+ & 0 & 0 & 3 & 2 & $3-$ & $1+$ & $; 1$ & 3 & 3 & 0 & 3 & 3 & 2 & 3 & 2 & 3 & 3 & 3 & 3 & 3 & 3 & 3 & 3 & 3 \\
\hline 23 & $\operatorname{Lr} 26^{\mathrm{d}+}$ & 0 & ; & ; & 0 & 0 & ; & ; & 0 & 0 & $; 1$ & ; & ; & 0 & 0 & 0 & 0 & 0 & ; & 0 & 3 & 0 & ; & 0 & $; 2$ \\
\hline 24 & Lr26+ & 2 & 3 & 3 & $2+$ & 3 & $1+$ & 1 & 3 & 3 & 2 & 3 & 3 & 2 & 3 & 0 & 3 & 3 & 3 & 3 & 3 & 3 & 3 & 3 & 2 \\
\hline 25 & $\operatorname{Lr} 26+$ & 2 & $; 2$ & 3 & ;1 & ;2 & $1+$ & $1+$ & $; 2$ & 2 & 2 & 2 & 2 & 1 & 3 & 2 & 3 & 3 & 3 & 2 & 2 & ;2 & 3 & 3 & 3 \\
\hline 26 & $\operatorname{Lr} 26^{\mathrm{c}}+$ & 1 & 3 & 2 & 2 & 3 & 34 & 3 & $; 1$ & 12 & 0 & 2 & 3 & 1 & $; 1$ & 3 & ; & 3 & 3 & 2 & 2 & 2 & 3 & 4 & 3 \\
\hline 27 & Lrl & 3 & ; & $1+$ & 3 & 3 & 4 & ; & 1 & 3 & ; & ; & 4 & ; & 1 & 4 & 3 & 4 & 3 & ; & $1+$ & 4 & 4 & 1 & 3 \\
\hline 28 & Lrl & 3 & 0 & 0 & 3 & 3 & 3 & 1 & 0 & 3 & ; & 0 & 3 & 0 & ; & 3 & 3 & 3 & 3 & 0 & ; & 3 & 4 & ; & 3 \\
\hline 29 & $\mathrm{Lrl+}$ & ; & 0 & 0 & 3 & 3 & 4 & 1 & 0 & ; & 0 & 0 & 3 & 0 & ; & 3 & 3 & 3 & ; & ; & 0 & 0 & 4 & ; & 3 \\
\hline 30 & Lrl+ & 3 & ; & ; & 0 & 3 & $1+$ & $; 1$ & ; & 0 & 0 & 0 & 3 & 0 & 0 & ; & 3 & 3 & ; & 0 & 0 & 3 & 3 & 0 & 3 \\
\hline 31 & $\begin{array}{l}\text { Lrl, } \\
\text { Lr26+ }\end{array}$ & $; 2$ & ; & ; & ; & $; 1$ & 1 & $; 1$ & $; 1$ & ; & $; 1$ & ; & 1 & ; & 1 & 0 & 0 & 2 & ; & ; & 0 & 0 & ;1 & ; & 3 \\
\hline 32 & Lrl6+ & 2 & 0 & 2 & ;1 & $1+$ & 4 & 3 & 2 & 2 & 2 & 2 & 2 & 3 & 2 & 1 & 2 & 2 & 2 & 12 & 3 & 2 & $3-$ & 2 & 1 \\
\hline 33 & $\begin{array}{l}\operatorname{Lr} 26^{\mathrm{d}} \\
\operatorname{Lr} 24\end{array}$ & 0 & 0 & 0 & 0 & 0 & 0 & 0 & 0 & 0 & 0 & 0 & 0 & 0 & 0 & 0 & 0 & 0 & 0 & 0 & 0 & 0 & 0 & 0 & 0 \\
\hline 34 & Lr24 & 0 & ; & 0 & 0 & 0 & ; & 0 & 0 & 0 & 0 & & 0 & 0 & 0 & 0 & 0 & 0 & 0 & 0 & ; & 0 & 0 & 0 & 0 \\
\hline 35 & $\begin{array}{l}\text { Lr3ka, } \\
\text { Lr16+ }\end{array}$ & 3 & 2 & 1 & 2 & $; 2$ & 3 & 3 & 2 & $; 1$ & $; 2$ & 2 & 2 & 2 & 1 & 0 & $; 1$ & 2 & 2 & $; 1$ & 3 & $2+$ & 4 & 2 & 2 \\
\hline 36 & $\begin{array}{l}\text { Lr26, } \\
\text { Lr16, } \\
\text { Lr3ka+ }\end{array}$ & 3 & 1 & 2 & 2 & $1+$ & $1+$ & 1 & 2 & 2 & ; & 2 & 2 & 0 & 3 & 1 & 0 & $1+$ & 2 & 2 & 3 & 2 & 4 & 2 & 2 \\
\hline 37 & Lr17a+ & ;2 & 1 & 1 & 1 & $1+, 2$ & 3 & $3 \mathrm{C}$ & 2 & 2 & 2 & 3 & 3 & 2 & 2 & 1 & 3 & 2 & 3 & 2 & 2 & 3 & 3 & 3 & 2 \\
\hline 38 & Lrl7a+ & 2 & 0 & 1 & 2 & 2 & 4 & 4 & 2 & 2 & 2 & 3 & 3 & 2 & 2 & 3 & 3 & ; & 2 & 1 & 3 & 2 & 3 & 2 & 1 \\
\hline 39 & $\begin{array}{l}\text { Lr3ka, } \\
\text { Lr17a }\end{array}$ & 2 & $2+$ & 2 & $2+$ & 2 & $3+$ & $3+$ & 2 & 2 & 2 & 3 & 3 & 2 & 1 & 2 & 2 & 2 & 3 & 1 & 2 & $1+$ & 3 & 3 & 2 \\
\hline 40 & $\begin{array}{l}\text { Lr26, } \\
\text { Lr3ka, } \\
\text { Lr16, } \\
\text { Lr17a+ }\end{array}$ & 2 & 2 & 2 & 2 & 2 & ; & 1 & 2 & 2 & 0 & 2 & 3 & 2 & 2 & ; & 2 & 2 & 3 & 2 & 3 & 2 & 3 & 2 & $1+$ \\
\hline 41 & $\begin{array}{l}\text { Lr26, } \\
\text { Lr14a+ }\end{array}$ & ; & 0 & 3 & 0 & 0 & 1 & $; 1$ & 0 & ; & 0 & ; & ; & 0 & ; & 0 & $; 1$ & ; & ; & 0 & 2 & ; & ; & ; & 2 \\
\hline 42 & $\begin{array}{l}\text { Lr26, } \\
\text { Lr14a+ }\end{array}$ & 2 & 3 & 3 & 2 & 2 & 1 & 1 & 2 & 2 & ; & 3 & 2 & 1 & 2 & 0 & 2 & 3 & $; 2$ & ;1 & 2 & 3 & 3 & $3-$ & 1 \\
\hline 43 & $\begin{array}{l}\text { Lr26, } \\
\text { Lr14a+ }\end{array}$ & $; 2$ & 0 & 3 & ;2 & $; 2$ & ; & ; & 2 & 0 & 0 & 3 & 1 & ; & 1 & 0 & 2 & 3 & ; & 0 & 0 & 3 & 3 & 3 & 0 \\
\hline 44 & $\begin{array}{l}\text { Lr26, } \\
\text { Lr14a+ }\end{array}$ & ; & 0 & ; & ;1 & ;2 & 1 & 1 & 2 & 1 & $; 2$ & 3 & 1 & 1 & ; & ; & $; 2$ & 3 & 3 & ;2 & 0 & ;2 & 3 & $3-$ & 2 \\
\hline 45 & $\begin{array}{l}\text { Lr3ka, } \\
\text { Lr14a+ }\end{array}$ & $; 2$ & 2 & 3 & ;1 & ;1 & ; & 1 & 2 & 0 & ; & ; & 1 & 0 & ; & ; & 0 & ; & ; & 0 & 2 & $0 ; 2$ & 4 & ; & 1 \\
\hline 46 & Lrl4a+ & 3 & $0 ; 2$ & 0 & 3 & 3 & ; & ; & 0 & 0 & 3 & 0 & $; 1$ & 0 & 0 & 3 & 0 & $2+$ & 3 & 0 & 0 & 0 & 3 & ; & ; \\
\hline 47 & Lrl4a+ & 3 & $; 0$ & ; & 0 & 3 & ; & ; & 0 & 0 & 0 & ; & 1 & 2 & 3 & 0 & 0 & 3 & ; & 0 & 0 & 3 & 4 & 0 & ; \\
\hline
\end{tabular}

(continued on next page)

a According to the 0-4 Stakman scale as modified by Roelfs et al. (26).

${ }^{\mathrm{b}}$ Line numbers correspond to those in Table 1 and are arranged in groups according to postulated $\mathrm{Lr}$ genes.

${ }^{\mathrm{c}}$ Postulation of 1BL.1RS was based on molecular markers. These lines were susceptible to all or some of four $\operatorname{Lr} 26$-avirulent pathotypes.

${ }^{\mathrm{d}}$ Postulation of 1BL.1RS was based on molecular markers. These lines were resistant to all or most of pathotypes.

e Postulation of Lr34 was based on molecular markers. These lines also showed symptoms of leaf tip necrosis (Ltn) and lower disease severity at the adultplant stage. 
Infection types to Puccinia triticina pathotypes

$\begin{array}{llllllllllllllllllllllllll}\text { Line } & L r & \text { PH } & \text { FC } & \text { FC } & \text { PC } & \text { TC } & \text { PG } & \text { FG } & \text { FK } & \text { PC } & \text { FB } & \text { FH } & \text { PH } & \text { FH } & \text { FH } & \text { PG } & \text { PC } & \text { TC } & \text { PH } & \text { FH } & \text { FH } & \text { PH } & \text { TH } & \text { FC } & \text { PC }\end{array}$

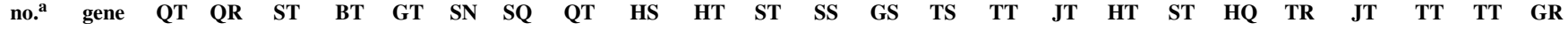

\begin{tabular}{llllllllllllllllllllllllllll}
\hline 48 & Lr26, & 2 & 3 & 3 & $2+, 3-$ & $3-$ & $1+$ & $;$ & 2 & 1 & 2 & 3 & 2 & 2 & 2 & 2 & 3 & 3 & 2 & 2 & 2 & 3 & 3 & 3 & 3
\end{tabular} Lrl8+

$49 \quad \operatorname{Lr} 26$,

Lr18+

50 Lr26, $\quad 2 \quad \begin{array}{lllllllllllllllllllllllllll} & 0 & 3 & ; 1 & 2 & 1 & 1 & 2 & 2 & 0 & 3 & 1 & 0 & 1 & 2+ & 2+ & 3 & 3 & 2 & 3 & 3- & 3 & 3- & 2\end{array}$

Lr18+

$\begin{array}{lllllllllllllllllllllllllll}51 & \operatorname{Lr} 26, & ; & 3 & 3 & 3 & 3 & 1 & 0 ; & ; 2 & ; 1 & 0 ; & 3 & 2 & 0 & ; & 0 & 0 ; & 3 & 2 & ; 2 & 3 & 3 & 3 & 3 & ; 1\end{array}$ Lr18+

$\begin{array}{lllllllllllllllllllllllllll}52 & \text { Lr3bg+ } & ; 2 & 0 & 1 & ; 2 & ; & 3 & 3 & ; 2 & 2 & ; & 2 ; & 3 & 1 & 1 & 1 & 3 & 2 & ; 1 & ; & 1 & 3 & 3 & ; & 3\end{array}$

$\begin{array}{lllllllllllllllllllllllllll}53 & \operatorname{Lr} 26, & 3 & ; 2 & 3 & 3 & 2+ & 1+ & 1+ & 3 & 3 & 0 ; & 3 & 2 & ; 2 & 3 & 0 & 3 & 2 & 2 & 1 & 2 & 3 & 3 & 3 & 3\end{array}$ Lr3bg+

$54 \begin{array}{llllllllllllllllllllllllllll}\mathrm{L} 2 \mathrm{a} a & ; & 0 & 0 & 0 ; & 3 & 1 & ; & ; & 0 & ; & 0 & ; & 0 & 0 & 1 & ; & 2 & ; & 0 & 0 & 0 & 4 & 0 ; & 0 ;\end{array}$ $\begin{array}{lllllllllllllllllllllllllllllll}\text { Lr3bg } & & & & & \end{array}$

Lrl,

Lr20+

56 Lr16,

$\operatorname{Lr} 20$

Lr23+

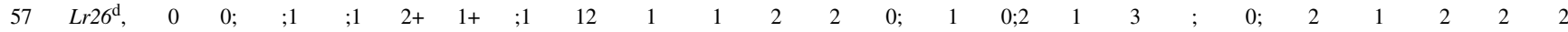
LrZH84

$58 \quad \operatorname{Lr} 26^{\mathrm{d}}$, LrZH84

59 Lr26, $\operatorname{Lr} 34^{\mathrm{e}}$

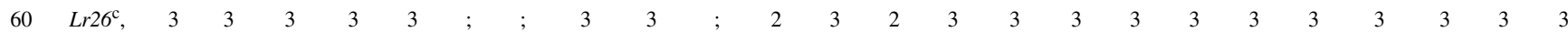
$\operatorname{Lr} 34^{\mathrm{e}}$

$\begin{array}{llllllllllllllllllllllllll}61 & \operatorname{Lr} 34^{\mathrm{e}} & 3 & 3 & 3 & 4 & 3 & 1 & 3 & 3 & 3 & 3 & 3 & 3 & 3 & 3 & 3 & 3 & 3 & 3 & ; 2 & 3 & 3 & 3 & 3 & 3\end{array}$

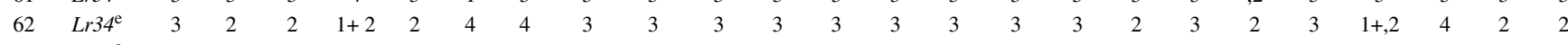

$\begin{array}{lllllllllllllllllllllllllllllll}63 & \text { Lr34 } & 4 & 4 & 4 & 4 & 4 & 4 & 3 & 4 & 4 & 4 & 4 & 4 & 4 & 3+ & 4 & 4 & 4 & 4 & 4 & 4 & 4 & 4 & 4 & 4\end{array}$

$64 \begin{array}{llllllllllllllllllllllllll} & \operatorname{Lr} 34^{\mathrm{e}} \quad ; & 0 ; 2 & ; & 3 & 3 & 3- & ; 1 & 3 & 3 & 3 & ; & 3 & 0 & 3 & 0 & 3 & 3 & ; & 0 & 0 & 3 & 4 & 0 & 3\end{array}$

$\begin{array}{lllllllllllllllllllllllllllll}65 & \text { Lr34 } & 3+ & 4 & 3+ & 3+ & ; & 4 & 4 & 4 & 4 & 3 & 4 & 4 & 4 & 4 & 4 & 4 & 4 & 3+ & 4 & 3 & 4 & 4 & 4 & 4\end{array}$

$66+\begin{array}{llllllllllllllllllllllllll} & 2 & 0 & 3 & 2 & 2 & 3 & 2 & 2 & 3 & 3 & 3 & 3 & 3 & 3 & 2 & 3 & 3 & 3 & 2 & 3 & 2+ & 3 & 2 & 3\end{array}$

$67+0 \begin{array}{lllllllllllllllllllllllll}6 & + & 0 & 0 & 0 & ; & 0 & 0 & 0 & 0 & 0 & 0 & 0 & 0 & 0 & 0 & 0 & 0 & ; & 0 & 0 & 0 & 0 & 0 & 0\end{array}$

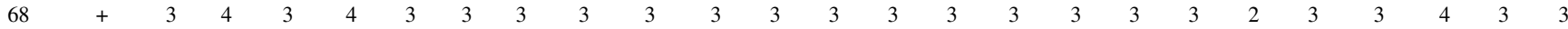

$69+\begin{array}{lllllllllllllllllllllllll} & 3 & 2 & 2 & 1+2 & 2 & 3+ & 4 & 2 & 3 & 3 & 3 & 2 & 2 & 3 & 3 & 2 & 2+ & 3 & 2 & 3 & 1+, 2 & 3 & 2 & 2\end{array}$

$70+$
7

\begin{tabular}{l}
$71+$ \\
\hline
\end{tabular}

$\begin{array}{ccccccccccccccccccccccccccc}72 & + & 4 & 4 & 4 & 4 & 4 & 4 & 4 & 4 & 4 & ; 1 & 3 & 3 & 4 & 4 & 4 & 4 & 4 & 3 & 3 & 4 & 4 & 4 & 4 & 4 \\ 73 & + & 1+ & 4 & 2+, 3- & 3 & 3 & 4 & 4 & 3 & 4 & 0 & 4 & 3 & 4 & 4 & 4 & 4 & 4 & 3 & 4 & 3 & 4 & 4 & 3 & 4\end{array}$

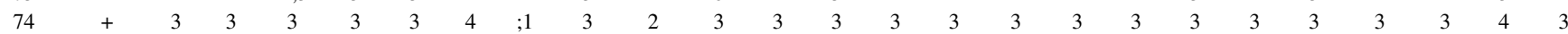

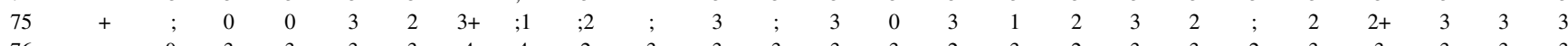

$76+0 ;$
+

$77+\begin{array}{lllllllllllllllllllllllll}7 & + & 0 & 3 & 2 & 3- & 4 & 3+ & 3 & 3 & 3 & 3 & 3 & 2 & 3 & 0 & 3 & 3 & 2 & 3 & 3 & 2+, 3- & 3 & 3- & 2\end{array}$

$\begin{array}{lllllllllllllllllllllllllll}78 & + & 4 & 4 & 3 & 4 & 3 & 4 & 4 & 4 & 4 & ; & 3 & 4 & 4 & 4 & 4 & 4 & 4 & 3 & 4 & 4 & 4 & 4 & 4 & 4 \\ 79 & + & 3 & 3 & 3 & 4 & 3 & 4 & 4 & 2 & 2 & 3 & 3 & 3 & 2 & 3 & 3 & 3 & 3 & 3 & 3 & 2 & 3 & 4 & 4 & 3\end{array}$

\begin{tabular}{l}
$80+$ \\
\hline
\end{tabular}

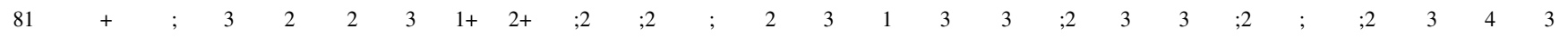

$82+$
2

83
+

\begin{tabular}{l}
$84+$ \\
\hline+
\end{tabular}

\begin{tabular}{l}
85 \\
\hline
\end{tabular}

86
+

$\begin{array}{lllllllllllllllllllllllllll}87 & + & 4 & 4 & 4 & 4 & 4 & 4 & 4 & 4 & 4 & 4 & 4 & 4 & 4 & 4 & 4 & 4 & 4 & 4 & 4 & 4 & 4 & 4 & 4 & 4 \\ 88 & + & 4 & 4 & 4 & 4 & 4 & 4 & 4 & 4 & 4 & 3 & 4 & 4 & 4 & 4 & 4 & 4 & 4 & 4 & 4 & 4 & 4 & 4 & 4 & 4\end{array}$

$\begin{array}{lllllllllllllllllllllllllll}89 & + & 4 & 4 & 4 & 4 & 4 & 4 & 4 & 4 & 4 & 4 & 4 & 4 & 4 & 4 & 4 & 4 & 4 & 4 & 4 & 4 & 4 & 4 & 4 & 4\end{array}$

90
+

$\begin{array}{rllllllllllllllllllllllllll}91 & + & 4 & 4 & 4 & 4 & 4 & 4 & 4 & 4 & 4 & 4 & 3 & 3 & 4 & 3 & 4 & 4 & 4 & 4 & 4 & 4 & 4 & 4 & 4 & 4 \\ 92 & + & 4 & 4 & 3+ & 4 & 4 & 3+ & 4 & 3 & 4 & 4 & 4 & 4 & 4 & 4 & 4 & 4 & 4 & 3 & 4 & 3 & 4 & 4 & 4 & 4\end{array}$

93
+

94
+

$\begin{array}{rllllllllllllllllllllllllll}95 & + & 4 & 4 & 4 & 4 & 4 & 4 & 4 & 4 & 4 & 4 & 3 & 3 & 4 & 4 & 4 & 4 & 4 & 4 & 4 & 4 & 4 & 4 & 4 & 4 \\ 96 & + & 4 & 4 & 4 & 4 & 4 & 4 & 4 & 3 & 4 & 4 & 3 & 4 & 4 & 4 & 4 & 4 & 4 & 4 & 4 & 4 & 4 & 4 & 4 & 4\end{array}$

$97+$
+

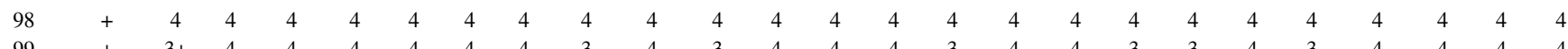

$100+\begin{array}{llllllllllllllllllllllllll}4 & + & 4 & 4 & 3 & 4 & 4 & 4 & 4 & 4 & 4 & 4 & 4 & 4 & 4 & 4 & 4 & 4 & 4 & 4 & 4 & 4 & 4 & 4 & 4\end{array}$

$\begin{array}{llllllllllllllllllllllllll}101 & + & 4 & 4 & 4 & 4 & 4 & 4 & 4 & 4 & 4 & 3 & 4 & 4 & 4 & 4 & 4 & 4 & 4 & 4 & 4 & 4 & 4 & 4 & 4 & 4 \\ 102 & + & 3+ & 4 & 4 & 4 & 4 & 4 & 4 & 4 & 4 & 4 & 4 & 4 & 4 & 4 & 4 & 4 & 4 & 4 & 4 & 4 & 4 & 4 & 4 & 4\end{array}$ 
genes, Lrl, Lr3, Lr3bg, Lr9, Lr10, Lr13, Lr16, Lr23, Lr26, and Lr34, in 47 new wheat cultivars from China using 17 pathotypes of $P$. triticina. Six of them, Lr1, Lr3bg, Lr16, Lr23, Lr26, and Lr34, were also identified in our seedling tests. The postulation of genes $L r 3, L r 9$, and LrlO was not possible in the present study because high ITs or low ITs were recorded the seedling tests because the gene is an APR gene.

During the early 1970s, the 1BL.1RS translocation with $\operatorname{Yr} 9$ and $L r 26$ for resistance to stripe rust ( $P$. striiformis $\mathrm{f}$. sp. tritici) was introduced to Chinese wheat breeding programs through the introduction of wheat germplasm such as Lovrin 10, Lovrin 13, Predgornaia 2, Kavkaz, and Neuzucht (9), leading to a high frequency of Lr26 in Chinese wheat cultivars and lines. Among 102 wheat lines tested in the present study, Lr26 was identified in 44 $(43.1 \%)$. Three lines $($ L13 = Zhoumai 12 , L26 = N711, and L60 = R97) were suscepwith all pathotypes. $\operatorname{Lr} 13$ was not tested in

tible to all or some of four $\operatorname{Lr} 26$-avirulent pathotypes, but had a 1BL.1RS translocation based on the test with molecular markers. This indicated that an inhibitor gene might suppress the expression of Lr26 in these two lines, or that a 1BL.1RS translocation lacking $\operatorname{Lr} 26$ might be present. Hanušová et al. (8) reported an inhibitor of $P m 8$ in certain 1BL.1RS wheat genotypes, but suppression of leaf rust resistance gene $L r 26$ has not been reported and therefore needs to be verified.

Lrl was postulated to be present in seven cultivars and lines. A study by Singh et al. (31) indicated that $\mathrm{Lrl}$ was present in many Chinese cultivars. Lrl in Yumai 47 might be derived from Baiquan 3199, because Bainong 3217 with $\operatorname{Lrl}$ (31) had the same parent, Funo, as Baiquan 3199, indicating that Lrl in Yumai 47 and Bainong 3217 was likely derived from Funo. $\mathrm{Lrl}$ in Lumai 21 might be derived from Lumai 13 (Table 1), because Baiyoubao carrying Lrl (31) was one of the parents of Lumai 13. Lrl in Emai 14 was derived from Yanda

Table 4. Analysis of variance of relative area under the disease progress curve (rAUDPC) and maximum disease severity (MDS) in 104 wheat cultivars and lines including slow rusting and susceptible checks tested in Baoding in the 2006-07 and 2007-08 cropping seasons

\begin{tabular}{llrrrc}
\hline Parameter & Source of variation & df & MS & $\boldsymbol{F}$ value & $\boldsymbol{P}$ \\
\hline rAUPDC & Cultivar & 103 & $5,710.81$ & 72.00 & $<0.0001$ \\
& Season & 1 & $1,745.76$ & 21.94 & $<0.0001$ \\
& Replication & 2 & 58.71 & 0.74 & 0.48 \\
& Cultivar*season & 103 & $1,005.96$ & 12.68 & $<0.0001$ \\
& Cultivar*replication & 206 & 78.24 & 0.99 & 0.54 \\
MDS & Error & 208 & 79.34 & & $<0.0001$ \\
& Cultivar & 103 & $5,595.44$ & 112.53 & $<0.0001$ \\
& Season & 1 & $21,443.85$ & 431.27 & 0.35 \\
& Replication & 2 & 52.15 & 1.05 & $<0.0001$ \\
& Cultivar*season & 103 & 930.84 & 18.72 & 0.39 \\
& Cultivar*replication & 206 & 51.73 & 1.04 & \\
\hline
\end{tabular}

72-629, as Emai 14 and Bainong 64 carrying $L r l$ had the same parent Yanda 72-629 (31). Lrl in Neixiang 991 might be derived from Bainong 3217 based on its pedigree (Table 1). Lrl6, detected in five lines, was postulated in En 1, in agreement with the result reported by Singh et al. (31). Lrl6 in Zhengmai 9023 and Shaannong 981 might be derived from Shaan 213 and Xiaoyan 6 (31), respectively, according to their pedigrees (Table 1). Most lines with $\operatorname{Lrl}$ and Lr16 were highly susceptible to pathotype THTT at the adult plant stage. Genes $L r 3 k a, L r 14 a, L r 17 a$, and $L r 18$ could be present in some lines (Tables 2 and 3); however, these postulations will require further verification because few avirulent pathotypes were available for testing, and the resistant reactions displayed by the four genes were vulnerable to genetic background of host and environment.

Various lines were widely resistant to many of the pathotypes used in the study, but the resistance could not be attributed to known leaf rust resistance genes. This indicates that new leaf rust resistance genes may be present in some lines. Genetic analyses are now being undertaken on lines with superior leaf rust resistance, and the results of those studies will permit an assessment of the postulations made herein. $L r l$ and an unknown $L r$ gene were identified in Tian 95HF2, and LrZH84 was detected in Xinong 1163-4 and Guizhou 98-18 using SSR markers (data not shown).

Slow rusting resistance. The 14 genotypes with slow leaf rusting resistance to THTT were tested as seedlings with all 24 $P$. triticina pathotypes. Twelve of them contained Lr26; two of those (L59 = 01018, and L60 = R97) carried Lr34 based

Table 5. Infection types (IT) ${ }^{\mathrm{a}}$ in the seedling test with Puccinia triticina pathotype THTT, presence and absence of the $1 \mathrm{~B} .1 \mathrm{R}$ wheat-rye chromosomal translocation and Lr34 based on molecular markers, and IT, mean maximum disease severity (MDS), and mean relative area under the disease progress curve (rAUDPC) in field experiments with the same pathotype in Baoding, Hebei in the 2006-07 and $2007-08$ growing seasons for wheat genotypes with slow rusting resistance to leaf rust

\begin{tabular}{|c|c|c|c|c|c|c|c|c|}
\hline \multirow{2}{*}{$\begin{array}{l}\text { Genotype } \\
\text { (line number) }\end{array}$} & \multirow{2}{*}{$\begin{array}{c}\text { Seedling } \\
\text { IT to THTT }\end{array}$} & \multirow{2}{*}{$\begin{array}{c}\text { 1B.1R } \\
\text { and } L r 34^{\mathrm{b}}\end{array}$} & \multicolumn{3}{|c|}{ 2006-07 } & \multicolumn{3}{|c|}{ 2007-08 } \\
\hline & & & IT & $\operatorname{MDS}(\%)$ & rAUDPC (\%) & IT & $\operatorname{MDS}(\%)$ & rAUDPC (\%) \\
\hline Saar ${ }^{\mathrm{c}}$ & 4 & Lr34 & 4 & 18 & 15.11 & 4 & 12 & 15.43 \\
\hline Zhengzhou 5389d & 4 & - & 4 & 100 & 100.00 & 4 & 85 & 100.00 \\
\hline (95)18 (L7) & 4 & 1B.1R & 3 & 4 & 2.22 & 4 & 18 & 20.31 \\
\hline Lantian 9 (L9) & 4 & 1B.1R & 3 & 7 & 5.89 & 4 & 22 & 25.14 \\
\hline Jing 035-1 (L12) & 4 & 1B.1R & 3 & 7 & 7.45 & 3,4 & 12 & 9.71 \\
\hline Lankao 906-4 (L18) & 3 & 1B.1R & 3 & 1 & 0.66 & 3,4 & 4 & 3.81 \\
\hline Huaimai 18 (L22) & 3 & 1B.1R & 3 & 7 & 5.78 & 4 & 13 & 15.43 \\
\hline 58749 (L40) & 3 & 1B.1R & 3 & 1 & 1.29 & 3 & 1 & 1.53 \\
\hline Y 1496-15 (L43) & 3 & 1B.1R & 3 & 1 & 0.85 & 3 & 7 & 5.67 \\
\hline LB0458 (L46) & 3 & - & 3 & 1 & 0.55 & 2,3 & 1 & 0.95 \\
\hline SW 8588 (L47) & 4 & - & 3 & 1 & 0.66 & 4 & 1 & 1.21 \\
\hline Mian 2000-13 (L51) & 3 & 1B.1R & 3 & 3 & 4.44 & 4 & 5 & 5.21 \\
\hline $351-15$ (L54) & 4 & - & 3 & 1 & 0.67 & 3 & 1 & 0.87 \\
\hline Neixiang 991 (L55) & 3 & 1B. $1 \mathrm{R}$ & 2,3 & 1 & 1.22 & 2,3 & 4 & 4.37 \\
\hline 01-018 (L59) & 4 & 1B.1R, Lr34 & 4 & 5 & 3.64 & 4 & 12 & 11.43 \\
\hline R97 (L60) & 3 & 1B.1R, Lr34 & 3 & 2 & 2.11 & 4 & 13 & 14.29 \\
\hline $\operatorname{LSD}(P=0.05)$ & & - & & 13 & 15.25 & & 15 & 14.36 \\
\hline
\end{tabular}

a According to the $0-4$ Stakman scale as modified by Roelfs et al. (26).

b $1 \mathrm{~B} .1 \mathrm{R}=$ presence of $1 \mathrm{~B} .1 \mathrm{R}, \operatorname{Lr} 34=$ presence of $L r 34,-=$ absence of $1 \mathrm{~B} .1 \mathrm{R}$ and $L r 34$.

c Slow rusting check.

d Susceptible check. 
on molecular marker detection. Four genotypes $(\mathrm{L} 40=58749, \mathrm{~L} 43=\mathrm{Y} 1496-15, \mathrm{~L} 51$ $=$ Mian 2000-13 , and L55 = Neixiang 991) had other known leaf rust resistance genes (Lrl, Lr3ka, Lr14a, Lr16, Lr17, Lr18, and Lr20), and two (L18 = Lankao 906-4, and L22 = Huaimai 18) likely possessed unidentified genes (Tables 3 and 4). In these genotypes, the seedling resistance gene(s) were overcome by pathotype THTT, and the slow rusting resistances probably resulted from Lr34 and other minor APR genes. Slow rusting resistance in LB 0458 (L46) may be derived from CIMMYT wheat germplasm (Table 1). Of all the slow leaf rusting cultivars and lines, 10 genotypes displayed slow rusting resistance to stripe rust (14). Slow rusting in these lines to both diseases might be conferred by common genes, as in the examples of $L r 34 / Y r 18$ and $L r 46 / Y r 29$ (15).

Singh et al. (33) reported that acceptable levels of slow rusting are conferred by combinations of minor additive genes. In the present study, we identified six lines with $L r 34$, but only two lines displayed a significant level of slow rusting resistance in the 2 years of field trials, indicating that Lr34 alone does not provide adequate resistance. However, Lr34 combined with other minor resistance genes can provide near-immune levels of leaf rust resistance.

\section{ACKNOWLEDGMENTS}

The authors are very grateful to R. A. McIntosh for reviewing this manuscript. This study was supported by the National Natural Science Foundation of China (30700505), National Scientific and Technical Supporting Programs funded by the Ministry of Science \& Technology of China (2006BAD08A05), and the Foundation of Hebei Education Department (2009 130).

\section{LITERATURE CITED}

1. Broers, L. H. M., Cuesta Subias, X., and Lopez Atilano, R. M. 1996. Field assessment of quantitative resistance to yellow rust in ten spring bread wheat cultivars. Euphytica 90:916.

2. Caldwell, R. M. 1968. Breeding for general and/or specific plant disease resistance. Pages 263-272 in: Proc. 3rd Int. Wheat Genetics Sympos. K. W. Findlay and K. W. Shepherd, eds. Australian Academy of Science, Canberra, Australia.

3. Chen, W. Q., Qin, Q. M., Chen, Y. L., and Wang, H. W. 1998. Preliminarily screening of slow leaf-rusting in the adult plant period in Chinese wheat cultivars. Southwest China J. Agric. Sci. 11:54-61.

4. Dong, J. G.. 2001. Agricultural Plant Pathology. China Agriculture Press, Beijing.

5. Dyck, P. L. 1987. The association of a gene for leaf rust resistance with the chromosome 7D suppressor of stem rust resistance in common wheat. Genome 29:467-469.

6. Dyck, P. L., and Samborski, D. J. 1982. The inheritance of resistance to Puccinia recondita in a group of common wheat cultivars. Can. J. Genet. Cytol. 24:273-283.
7. Flor, H. H. 1942. Inheritance of pathogenicity in Melampsora lini. Phytopathology 32:653669.

8. Hanušová, R., Hsam, S. L. K., Bartoš, P., and Zeller, F. J. 1996. Suppression of powdery mildew resistance gene Pm8 in Triticum aestivum L. (common wheat) cultivars carrying wheat-rye tranlocation T1BL·1RS. Heredity 77:383-387.

9. He, Z. H., Rajaram, S., Xin, Z. Y., and Zhang, G. Z. 2001. A history of wheat breeding in China. CIMMYT, Mexico, D.F.

10. Kilpatrick, R. A. 1975. New wheat cultivars and longevity of rust resistance, 1971-1975. U.S. Dep. Agric., Agric. Res. Serv.

11. Kolmer, J. A. 2003. Postulation of leaf rust resistance genes in selected soft red winter wheats. Crop Sci. 43:1266-1274.

12. Krattinger, S. G., Lagudah, E. S., Spielmeyer, W., Singh, R. P., Huerta-Espino, J., McFadden, H., Bossolini, E., Selter, L. L., and Keller, B. 2009. A putative ABC transporter confers durable resistance to multiple fungal pathogens in wheat. Science 323:1360-1363.

13. Lagudah, E. S., McFadden, H., Singh, R. P., Huerta-Espino, J., Bariana, H. S., and Spielmeyer, W. 2006. Molecular genetic characterization of the $L r 34 / Y r 18$ slow rusting resistance gene region in wheat. Theor. Appl. Genet. 114:21-30.

14. Li, Z. F., Xia, X. C., Zhou, X. C., Niu, Y. C., He, Z. H., Zhang, Y., Li, G. Q., Wan, A. M., Wang, D. S., Chen, X. M., Lu, Q. L., and Singh, R. P. 2006. Seedling and slow rusting resistance to stripe rust in Chinese common wheats. Plant Dis. 90:1302-1312.

15. Lillemo, M., Asalf, B., Singh, R. P., HuertaEspino, J., Chen, X. M., He, Z. H., and Bjornstad, A. 2008. The adult plant rust resistance loci $L r 34 / Y r 18$ and $L r 46 / Y r 29$ are important determinants of partial resistance to powdery mildew in bread wheat line Saar. Theor. Appl. Genet. 116:1155-1166.

16. Long, D. L., and Kolmer, J. A. 1989. A North American system of nomenclature for $P u c$ cinia recondita f. sp. tritici. Phytopathology 79:525-529.

17. McIntosh, R. A. 1992. Close genetic linkage of genes conferring adult-plant resistance to leaf rust and stripe rust in wheat. Plant Pathol. 41:523-527.

18. McIntosh, R. A., Devos, K. M., Dubcovsky, J., Rogers, W. J., Morris, C. F., Appels, R., Somers, D. J., and Anderson, O. A. 2008. Catalogue of gene symbols for wheat: 2008 supplement. Annu. Wheat Newsl. Vol. 54.

19. McVey, D. V. 1992. Genes for rust resistance in International Winter Wheat Nurseries XII through VXII. Crop Sci. 32:891-895.

20. McVey, D. V., and Long, D. L. 1993. Genes for leaf rust resistance in hard red winter wheat cultivars and parental lines. Crop Sci. 33:13731381.

21. Mebrate, S. A., Dehne, H. W., Pillen, K., and Oerke, E. C. 2008. Postulation of seedling leaf rust resistance genes in selected Ethiopian and German bread wheat cultivars. Crop Sci. 48:507-516.

22. Oelke, L. M., and Kolmer, J. A. 2004. Characterization of leaf rust resistance in hard red spring wheat cultivars. Plant Dis. 88:11271133.

23. Person, C. 1959. Gene-for-gene relationships in host: Parasite systems. Can. J. Bot. 37:11011130.

24. Peterson, R. F., Campbell, A. B., and Hannah,
A. E. 1948. A diagrammatic scale for estimating rust intensity of leaves and stems of cereals. Can. J. Res. 26:496-500.

25. Pink, D. A. C. 2002. Strategies using genes for non-durable disease resistance. Euphytica 124:227-236.

26. Roelfs, A. P., Singh, R. P., and Saari, E. E. 1992. Rust diseases of wheat: Concepts and methods of disease management. CIMMYT, Mexico, D.F.

27. Samborski, D. J. 1963. A mutation in Puccinia recondita Rob. ex Desm. f. sp. tritici to virulence on transfer, Chinese Spring $\times$ Aegilops umbellulata Zhuk. Can. J. Bot. 41:475-479.

28. Singh, R. P. 1992. Association between gene Lr34 for leaf rust resistance and leaf tip necrosis in wheat. Crop Sci. 32:874-878.

29. Singh, R. P. 1992. Genetic association of leaf rust resistance gene $\mathrm{Lr} 34$ with adult plant resistance to stripe rust in bread wheat. Phytopathology 82:835-838.

30. Singh, R. P. 1993. Resistance to leaf rust in 26 Mexican wheat cultivars. Crop Sci. 33:633637.

31. Singh, R. P., Chen, W. Q., and He, Z. H. 1999. Leaf rust resistance of spring, facultative, and winter wheat cultivars from China. Plant Dis. 83:644-651.

32. Singh, R. P., and Gupta, A. K. 1991. Genes for leaf rust resistance in Indian and Pakistani wheats tested with Mexican pathotypes of Puccinia recondita f. sp. tritici. Euphytica 57:27-36.

33. Singh, R. P., Huerta-Espino, J., and Rajaram, S. 2000. Achieving near-immunity to leaf and stripe rusts in wheat by combining slow rusting resistance genes. Acta Phytopathol. Hung. 35:133-139.

34. Singh, R. P., Mujeeb-Kazi, A., and HuertaEspino, J. 1998. Lr46: A gene conferring slowrusting resistance to leaf rust in wheat. Phytopathology 88:890-894.

35. Singh, R. P., and Rajaram, S. 1991. Resistance to Puccinia recondita f. sp. tritici in 50 Mexican bread wheat cultivars. Crop Sci. 31:14721479

36. Singh, R. P., and Rajaram, S. 1992. Genetics of adult-plant resistance to leaf rust in 'Frontana' and three CIMMYT wheats. Genome 35:2431 .

37. Statler, G. D. 1984. Probable genes for leaf rust resistance in several hard red spring wheats. Crop Sci. 24:883-886.

38. Wamishe, Y. A., and Milus, E. A. 2004. Seedling resistance genes to leaf rust in soft red winter wheat. Plant Dis. 88:136-146.

39. Yuan, J. H., Liu, T. G., and Chen, W. Q. 2007. Postulation of leaf rust resistance genes in 47 new wheat cultivars at seedling stage. Sci. Agric. Sinica 40:1925-1935.

40. Zhang, L. J., Li, Z. F., Lillemo, M., Xia, X. C., Liu, D. Q., Yang, W. X., Luo, J. C., and Wang, H. Y. 2009. QTL mapping for adult-plant resistance to leaf rust in CIMMYT wheat cultivar Saar. Sci. Agric. Sinica 42:388-397.

41. Zhang, X. K., Liu, L., He, Z. H., Sun, D. J., He, X. Y., Xu, Z. H., Zhang, P. P., Chen, F., and Xia, X. C. 2008. Development of two multiplex PCR assays targeting improvement of bread-making and noodle qualities in common wheat. Plant Breed. 127:109-115.

42. Zhao, X. L., Zheng, T. C., Xia, X. C., He, Z. H., Liu, D. Q., Yang, W. X., Yin, G. H., and Li, Z. F. 2008. Molecular mapping of leaf rust resistance gene LrZH84 in Chinese wheat line Zhou 8425B. Theor. Appl. Genet. 117:1069-1075. 